\title{
Blood Relationship, Bolshevism, and Whoopie Parties
}

Gerald Winrod was worried. After establishing Defenders of the Faith in Salina, Kansas, in 1925, the fundamentalist preacher had seen several state antievolution campaigns go down to defeat. His pamphlet The Red Horse (1932) analyzed the nature and scope of the problem. Knowing that his readers were familiar with the apocalyptic imagery of the book of Revelation, Winrod argued that the red steed-traditionally representing war-was none other than Soviet Russia. ${ }^{1}$ What made Russia especially significant to Winrod was communism's intimate connection with evolution. Since belief in evolution-or "animalistic ancestry"led to atheism, and atheism led to communism, teaching evolutionary science had "opened the door" to the acceptance of communist ideas in the United States. After all, wrote Winrod, "Every leader of the Russian Revolution was, and is, an evolutionist." To illustrate the connection between communism and evolution, Winrod pointed to the "moral collapse" evident in Russia. Because of Soviet animalism, "A man in Russia may live with several women the same day, all as his wives, because 


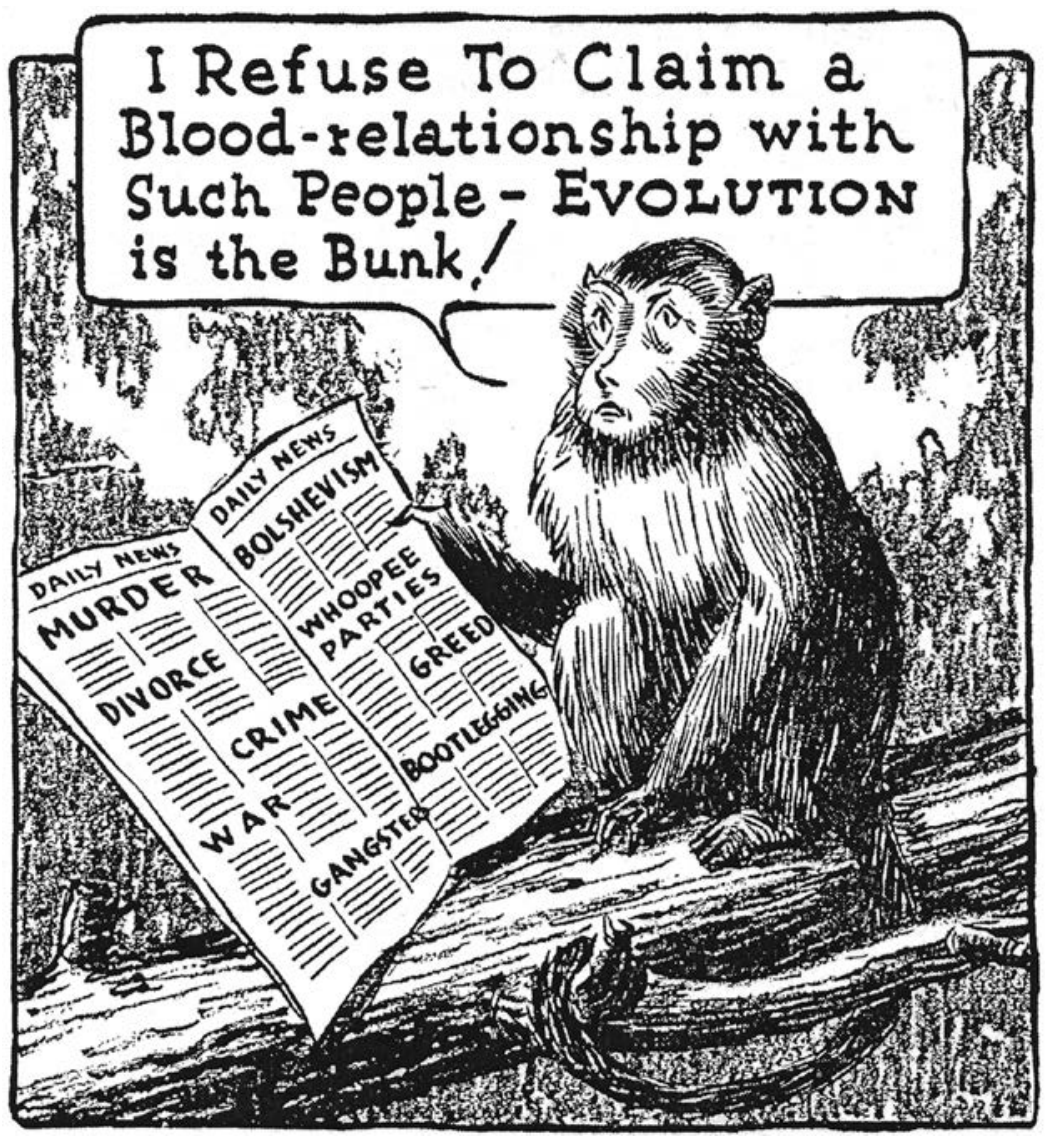

Figure 5. "EVOLUTION is the Bunk!" cartoon, 1930. Appearing in the July 1930 issue of Gerald Winrod's Defender magazine and exemplifying the "monkey-superior" genre that inverted the human-ape hierarchy, this cartoon conveyed the range of purported social and political evils Winrod attributed to evolution. Courtesy of Wichita State University Libraries, Special Collections and University Archives.

marriage and divorce are practically abolished." This resulted from an evolutionary logic: "Our ancestors observed no marriage laws in the jungles, so why should we?" As evidence that American schoolchildren were imbibing this "godless, beastly, antichrist thing," Winrod summarized a passage on the Darwinian concept of sexual selection in a popular high school psychology textbook. "Do not," he warned, "teach the 
children of America that they have the bodies, minds and sex-impulses of the beast and expect them to live clean, Godly lives." 2

By 1932, Defender readers were familiar with the themes Winrod raised in Red Horse: the apocalyptic role of Russia; the attribution of evolutionary thinking to Satan; the secret, manipulative methods of Moscow; the association of "free love" and immorality with the young Bolshevik Revolution; the allegations of moral decline in Russia and the United States, particularly linked to youth and sex; and the claims that revolutionary Russian leaders were evolutionists. Defender cartoons reinforced the message. One featured a monkey disclaiming any "blood relationship" with human beings, whose unsavory deeds, pictured in newspaper headlines, included "murder," "divorce," "Bolshevism," and "whoopee parties."3

Other leading fundamentalists during the 1920s-most notably William Bell Riley and J. Frank Norris, but also Mordecai Ham-were delivering a similar message. Unlike George McCready Price, these figures were not primarily identified as "creationists," but an anticommunist-inflected version of creationism was key to their fundamentalist activism. They reinforced each other's ideas and worked together in the World's Christian Fundamentals Association, which played a leading role in mobilizing the forces to ban the teaching of evolution. They preached in each other's pulpits and wrote for common publications. Their cohort included the theologically marginal Price, who was a contributing editor to the Defender and a guest speaker at a Defenders conference. More distantly, they were joined by George Barry O’Toole, a prominent Catholic professor of philosophy and biology and author of The Case against Evolution (1925). ${ }^{4}$ O'Toole also tied evolution to the dangers of socialist revolution. Together these thinkers made clear for conservative Christians that evolution posed a deadly danger to their worldly and eternal welfare.

It is appropriate that William Bell Riley, a man who figured so prominently in the conflicts within the Baptist Church, was born in deeply divided southern Indiana in 1861 exactly three weeks before the American Civil War began. ${ }^{5}$ Since his father, Branson Radish Riley, was a Kentuckian by birth and, by his son's account, a "slavery sympathizer," the family moved from Bloomfield, Indiana, in Greene County, back to the Bluegrass State within a month of William's birth. ${ }^{6}$ While Riley would come to be identified with his newly adopted home of Minneapolis, his second 
wife and biographer, Marie Acomb Riley, suggested that her "Kentuckian" husband retained his flair for southern "hospitality." He loved to tell jokes, "especially Negro stories," which contributed "spice" to conversations with friends. ${ }^{7}$ As this description of Riley appeared in a biography published in 1938 by Eerdmans, a prominent evangelical publisher based in Grand Rapids, Michigan, it speaks not so much to Riley's distinctive southern character as it does to the national reach of casual racism.

Looking back on his childhood, Riley wondered what effect the timing of his birth might have exerted on his personality. He thought the question was best left to psychologists, but there is no doubt that he enjoyed the art of intellectual brinksmanship. Riley traveled back into Indiana to earn a teaching certificate, hoping to become a lawyer. Compelled to return to his family farm, he felt the pull of the ministry, and stayed the course for the rest of his life. He graduated near the top of his class from orthodox Presbyterian-affiliated Hanover College in Hanover, Indiana, in 1885. Back across the border in Louisville, he earned a doctorate in divinity from Southern Baptist Theological Seminary in $1888 .^{8}$ Though never a lawyer by profession, Riley became a formidable advocate for the fundamentalist cause.

Riley's early assignments took him to southern Indiana, central Illinois, and then, from 1893 to 1897, the South Shore neighborhood of Chicago, where he was pastor of the newly formed Calvary Baptist Church. He preached blocks from the newly established University of Chicago, a bastion of Baptist modernism founded by John D. Rockefeller Jr. and William Rainey Harper. Riley's success in growing his young congregation and his ambition to pastor a large, centrally located urban congregation won him a prize position in 1897 at the blue-blooded First Baptist Church in downtown Minneapolis. In his new position, Riley remade the church in his own image. He took on the elite lay leadership of First Baptist and pushed for an open membership policy, regardless of social class, and for the abolition of the elitist practice of pew rentals. He cracked down on dancing, card playing, and theater. And the masses of Minneapolis Baptist faithful responded. Church membership nearly doubled the first year. Now ensconced in his pulpit, Riley founded the Northwestern Bible and Missionary Training School in $1902 .^{9}$

In his subsequent travels around the Midwest, Riley preached, as William Trollinger has noted, "standard revival fare." His messages on sin 
and salvation were laced with a strong dose of premillennial dispensationalism, which stressed the imminent Second Coming of Christ, a heavy emphasis on "signs" of that imminent return, and the inerrant truth of the Bible. He also took on the Socialists. Initially, his approach was to co-opt and channel the potentially radical sentiment. In one of his first sermons delivered in Chicago in September 1893, titled "Christ and Laboring Men," he explicitly addressed and praised "those who are counted among the laboring class," in company with Christ, the "lowly Nazarene" carpenter. ${ }^{10}$

By 1912, he was going for the political jugular. His chief text was Christianity vs. Socialism. ${ }^{11}$ Speaking in nearby Duluth, Minnesota, Riley zeroed in on the supposed socialist philosophy of replacing marriage with "mating." Without using the word "evolution," Riley complained about the socialist view that past societal norms needed to change-that the "social codes of the past have no more sacredness or binding authority for the modern man than the customs of the anthropoid ape should have for his human and educated descendant." He then charged socialists with proposing a "collectivist" form of marriage, which meant "free love" and the conversion of children into "wards of the state." As evidence, he quoted Bebel on the need to abolish both marriage and private property. In the booklet, Riley clarified for his readers that if they are attracted to the idea of the equal division of property, they must realize that this inevitably means "free love." This "doctrine of devils," writes Riley, will "degrade men and women to a level with the beasts of the field." In the Duluth speech, Riley described the socialist dystopia this way: "Men would fight for the possession of the most beautiful women and the streets of the civilized world would run with blood." 12 Without characterizing socialist ideas about "free love" as "evolutionary," the language Riley used"beasts," "savagery," and "blood"—resonated well with his developing critique of evolution.

As early as 1910, the decision of the Northern Baptist Convention to hold its national convention at the University of Chicago got Riley thinking more seriously about organizing the Baptist fundamentalists. The outbreak of World War I accelerated their growth. The capture of Jerusalem by the British and the prospects for a Jewish return to Palestine seemed to bear out biblical prophecy about the end times. By 1918, Riley was meeting with Reuben Torrey of the Bible Institute of Los Angeles to plan 
a prophecy conference for the next year, which Riley engineered into the founding meeting of the World's Christian Fundamentals Association (WCFA). In 1922, Riley convinced the WCFA that it should concentrate on evolution. The group provided the organizational base for successful passage of the antievolution Butler Act in Tennessee three years later. The WCFA flourished only through the late 1920s, but as its president and head of the Committee on Conferences, Riley kicked off its inauguration with great fanfare, leading a six-week tour of North America. ${ }^{13}$

Among the Bible institutes present at the 1919 Philadelphia conference was Riley's own Northwestern Bible Training School. It had grown steadily since its founding, owing largely to Riley's superb administrative and fund-raising skill. While he boasted that the school survived thanks to a multitude of small contributions, Riley also managed to enlist the help of wealthy supporters. ${ }^{14}$ His curriculum was distinguished from the education Riley had received at the Southern Baptist seminary, which had included a large degree of classical literature and biblical commentary. At Northwestern Bible, the focus was on reading and studying the plain "facts" of the Bible, with the clear fundamentalist guidance of superintendent William Bell Riley. ${ }^{15}$

Riley first addressed the Red connection to evolution in the early 1920s in a pair of sermons that he delivered at First Baptist: "The Theory of Evolution-Does It Tend to Anarchy?" (1922) and "Evolution or Sovietizing the State through Its Schools" (c. 1923). Delivered at the outset of the WCFA campaign against the teaching of evolution, "Anarchy" was based on Second Peter 2:1-12, in which the author warns of false prophets who would spout "damnable heresies" and lead the people astray with their "pernicious ways." Riley first claims that the "evolutionary hypothesis" propounded by such modern-day false prophets is "unproven." Then he argues that it was built on pure speculation, which has turned out to be "utterly false." Evolution is therefore "a lie," and as such, it cannot produce "desirable fruits." Rather it produces "social putridity," "social slavery," total absence of government, and more concretely, "BESTIAL BOLSHEVISM!"”16

Freely mixing anarchism and socialism, Riley quoted from anarchist Mikhail Bakunin to illustrate the "dominant" interpretation of socialism, but then provided as one of the few concrete examples of evolution's evil 
fruits the situation prevailing in the Soviet Union. Just as George McCready Price asked whom his readers would trust with a large sum of money, Riley wondered if any of his parishioners would feel safe bringing up their children in any country that had "tried out Evolutionary Socialism." Surely, answered Riley, they would not want to be in Russia. He borrowed from Price, retelling the horror story of children dancing all night in "brightly illuminated school buildings." Nor would they want to be in Germany, which, under the spell of Darwinism, had become "brazen and defiant as a nation-ravishing, maiming, poisoning, burning, suffocating, deporting, enslaving." In either case, the proponents of Darwinism were like the false prophets of Peter's time who bring about their own destruction. They were like "natural brute beasts, made to be taken and destroyed." ${ }^{17}$

Even more dangerous were promoters of evolutionary thinking right here in America who menaced the country. Borrowing again from Price, Riley gave the example of Bouck White, who used spiritual "dynamite" to attack the established capitalist order. ${ }^{18}$ Riley and Price agreed that at stake for American Christians in the battle over evolution was nothing less than morality and civilization. In a "godless world," warned Riley in the sermon, children would no longer honor their parents; parents would abandon their children, kill with impunity, steal without guilt, and "commit adultery without conscience." On this last point, comparing this socialist nightmare to current-day America, Riley explained that the law against adultery "was only made sacred by capitalism." ${ }^{19}$ Riley's rhetorical shift here from anticommunism to pro-capitalism anticipated a theme that became increasingly visible in later decades.

By 1926, Riley joined forces with Gerald Winrod, under the auspices of the Minnesota Anti-Evolution League, and both men were barnstorming the state. Riley gave sixty-five speeches. But in a stinging rebuke to Riley in March of that year, the University of Minnesota refused to give permission for the First Baptist pastor to speak on campus. Angry but undaunted, Riley spoke in Minneapolis's Kenwood Armory to more than five thousand people on the "white-hot" issue of evolution. He focused on natural and social science textbooks used in Minnesota public schools that contained evolutionary material. As before, he tied evolution to German philosophy, and at one point associated one of the textbook authors with defenders of the Bolsheviks. He wisely ended his talk with a populist 
appeal to the "God-fearing majority": "Whose university is it over there, will you tell me? Does it belong to a dozen regents? (A voice: No sir!) Does it belong to fifty or seventy-five professors? Does it? (No!)." ${ }^{20}$

Riley's "Sovietizing" sermon conveyed a more detailed and politically pointed message. To preempt any suspicion that his anticommunism might be masking a defense of wealth and privilege, Riley began by establishing his credentials as a "friend ... of the poor and oppressed." Despite his identification with the downtrodden, Riley warned his flock about the "menace of the Soviet." Knowing that his congregation might have heard that the word "Bolshevik" meant rule by the majority, Riley argued that a small minority now ruled Soviet Russia. They were motivated by "class hatred." As did Winrod and Norris, Riley granted that there was ample reason for such feelings to exist under Russian czarism. Nonetheless, he contended, such a movement was inevitably "dangerous," because whenever "ignorant masses" overthrow a ruling power, they risk coming under the rule of an even worse tyranny. This had now happened, Riley said, quoting Lenin to prove his point, as follows: "Today the revolution in the interest of socialism demands the absolute submission of the masses to the single will of those who direct the labor process." 21 Not only were the Bolsheviks tyrannical, but they were brutal. After offering a catalog of their actions, Riley quoted "one writer" who described the peril of Russian communism as "a brutal savagery which, like a wild beast, tortures and kills to vent its bestiality." 22

That wild beast had already appeared in two arenas of American life. One was the labor movement. Led by the Industrial Workers of the World and the radical socialists, workers were pressing the US government to extend diplomatic recognition to Bolshevik Russia. Citing the Lusk Committee, a state legislative body investigating seditious activities, Riley claimed that there were more than five hundred thousand "red agitators" in New York alone. They were circulating literature in "shops and factories" and had even held public rallies to popularize their cause. The second manifestation of Sovietism was more subtle and insidious: the influence of Darwinism in high schools and universities, including at the University of Minnesota. The "outstanding leaders" of "Sovietism" in America, declared Riley, were the "professors in our modern universities who are naturally materialistic in their conception of the universe." 23 
As he did at the Kenwood Armory, Riley highlighted a handful of evolutionary social science textbooks currently in use at the University of Minnesota and the city's North High School. Not a single one of those books taught biology: Maurice Parmelee, Criminology; Charles A. Ellwood, Sociology and Modern Social Problems; Edward A. Ross, Social Psychology; F. Stuart Chapin, Social Evolution; and Henry Reed Burch and S. Howard Patterson, American Social Problems. As Riley summarized their approach, morality was a creation of human beings in specific historical circumstances. So, too, the human mind evolved from animal intelligence; the family developed from "the very conditions of life itself" and was not created by divine authority; and Christianity evolved out of older religions and retained elements of "wizardry" and "magic." The subjective religious conversion experience could be explained by the phenomena of hypnosis, the power of suggestion, and the subconscious mind. In short, the young people of Minnesota were learning from "God-denying, Christ-repudiating, Bible-scorning" textbooks. ${ }^{24}$

Evolutionary teachings were so dangerous, Riley explained to his flock, because they built a bridge that enabled an invasion of "Soviet propaganda." The textbook authors were not socialists, but their materialistic ideas, fueled by the scholarship of higher criticism, paved the way for Marxism. With swarms of paid agitators already active in America, this infusion of communist ideas would lead to revolution. America would become like Russia: "infidelity, mental and moral; rapine, plunder, robberythese will be universal." Riley concluded his sermon with the following plea: "God forbid that we should be silent while America is thus being menaced and the immortal souls of all men are being thus imperiled." 25

For Riley and his supporters around the country, the importance of the debate over teaching evolution went far beyond the classroom and even the church. It was not only that the salvation of individual Christians was imperiled. Nothing less than the future of civilized life on earth was at stake. Did you want to live in a world in which rape, marital infidelity, robbery, and all forms of immorality were rife? That is the world that evolutionary teachings—starting in biology and moving into the social sciences-were threatening to create. They were doing so by opening the door to the atheistic Communists in Soviet Russia, who claimed to be fighting for a world run in the interest of working people, but who were 
actually a band of infidel criminals who needed to be fought at all costs. In delivering his message in Minneapolis to the Baptist faithful in 1923, Riley was pulling out all the stops.

As a crack organizer and administrator, Riley was not working alone. Having established the Northwestern Bible school two decades earlier, he now had a growing institutional base of operations. Published by Northwestern and edited by Riley, Christian Fundamentals in School and Church (CFSC) projected his message on a regular basis. In the AprilMay-June 1923 issue, readers learned about the fifth annual conference of the WCFA, held in Fort Worth, Texas, at J. Frank Norris's First Baptist Church. Expected speakers included William Jennings Bryan, Norris, Riley, and T.T. Shields, a prominent Baptist conservative in Toronto. It was also reported that a week later, Shields, Riley, and others presided over the founding conference of the Baptist Bible Union (BBU) in Kansas City, Missouri. ${ }^{26}$

Fueled by resistance to the growth of modernism, including theistic evolution, the BBU was an early incarnation of the separatist fundamentalist impulse within the northern Baptist church. As the convention call in the CFSC put it-drawing on Jesus's parable of the tares secretly planted in the wheat fields- "The tares of rationalism have been sown in both our schools and churches, and they have not only taken root but are now developing to such proportions as to demand attention." ${ }^{27}$ As an example of such "attention," T.T. Shields, who served as a member of the board of trustees of McMaster University in Toronto, led a protest campaign the following year when the school awarded an honorary degree to modernist Baptist William H.P. Faunce, then president of Brown University. While Shields did not accuse Faunce of communist leanings, the militancy of Shields's fundamentalism was reflected in the title of his 1924 article on Faunce in the Gospel Witness: "Why Some Individuals and Institutions Need to Be Blown Up with Dynamite."28

The Red connection to evolution emerged several times in the spring 1923 issue of Riley's paper. One item, based on a letter sent to editor Riley, reported on a "blasphemous" ceremony in Moscow on the previous Christmas, in which Komsomol members burned the "great dignitaries of the religions of the world" and mocked the biblical story of Christ's birth. In his letter, Riley's friend asked rhetorically whether such action was any 
different from the rejection of traditional Christianity by American modernists. Was it not just a different expression of the same "anti-Christ" spirit? "The question is so pertinent that it requires no discussion," was Riley's reply. While the young communists seem to have condemned world religions in an equal opportunity fashion, the CFSC headline was more partial: "Burning the Image of Christ in Effigy." 29

If that article did not make the connection between evolution (as a component of modernism) and communism explicit, an extensive piece by Baptist fundamentalist missionary T. A. Blalock did. ${ }^{30}$ It concerned an arena of conflict over communism and Christianity of increasing interest to fundamentalists as the twentieth century wore on: China. Based in the western Chinese city of Tai'an, Blalock sought to explain what he termed China's political "confusion"-the seemingly endless political instability that had prevailed since the reform period of the 1890s and then since the republican revolution of 1911. They key "fact" according to Blalock was that China was a "nation of liars," thus undermining any basis for trust and stable rule. This racial flaw, moreover, was accentuated by the Western education received by Chinese abroad. There they learned about the animal origins of humanity and the lack of an eternal moral code. This was especially true for students who attended Columbia University, which Blalock labeled "one of the most notorious hot beds of evolution and modernism." If Blalock had read the list of endorsements for Ludwig Katterfeld's Evolution magazine from that university later in the decade, he would not have been shocked. ${ }^{31}$

Within China, added Blalock, the situation was possibly worse. Since 1890, Chinese reform intellectuals had taken up the cudgel of Darwin in the battle to modernize China. They stressed its eugenic side, focusing on the dominant Han nationality and on the survival of the fittest, a lesson that China's humiliating defeat by Japan in 1905 emphasized with great clarity. They also tended toward neo-Lamarckianism, looking for a new Chinese who would thrive in modern conditions and pass racial improvements to the next generation. ${ }^{32}$ Regardless of these grand ambitions, what Blalock stressed about the "incoming tide of new thought" was the simple fact that in government schools, as in those in Tai' an, where he lived and worked, students were learning about "the ape origin of man."

These evolutionary teachings had alarming political implications. Just as the "evolution seminaries" in the US were paving the way for 
communism, so in China, wrote Blalock, was the "false science of evolution ... making this land ready for a hot bed of Socialism, Anarchy and Bolshevism." ${ }^{3}$ With evolution running rampant, Blalock warned, things were about to get much worse. Evolution-crazed revolutionaries would turn the Middle Kingdom upside down. Whether it was China, Russia, New York, or Minneapolis, the message from Riley and his counterparts on the subject of evolution was consistent. They pointed not only to the Bible and otherworldly salvation, but to the common moral and political dangers facing Christians in the here and now.

If Riley was the preeminent fundamentalist based north of the MasonDixon Line in the first half of the twentieth century, his southern counterpart would have to be J. Frank Norris (1877-1952). Norris and Riley were remarkably similar. They grew up in the rural South, earned degrees from the Southern Baptist seminary in Louisville (Norris was first in his class), pastored big-city First Baptist churches for decades (Norris in Fort Worth), founded independent Bible schools, edited fundamentalist publications, and campaigned against both evolution and communism. In some respects, however, Norris's early life and personality were sharply different. Born in 1877 in Dadeville, Alabama, of Warner and Mary (Davis) Norris, young Frank experienced the terror of an alcoholic father. Earning his living as a steelworker in Alabama and later as a cotton sharecropper in Arkansas and Texas, Warner Norris drank much of his meager earnings away. He was physically abusive, once beating Frank when the boy dared to pour out his precious bottles of liquor in a vain attempt to protect his mother. When Frank was fifteen, he and his father were nearly killed when some local cattle rustlers, hearing that Warner was prepared to testify against them, appeared on their farm and started shooting. In a reflection of his combative spirit, Frank came at them with a knife and lived, barely, to tell the tale. ${ }^{34}$

The violent confrontations of Frank Norris's childhood continued in adult life. In 1912, Norris was tried for arson, when the First Baptist Church of Fort Worth, which he began pastoring in 1909, burned to the ground. It seems that his aggressive campaigning for prohibition had provoked local liquor interests to frame him. Hired gunmen twice shot at Norris on the street. But the attempt to frame Norris for the arson failed, and he was acquitted in a jury trial. Norris became best known for a second trial, in 1926, in which he was again the criminal defendant. Sitting in 


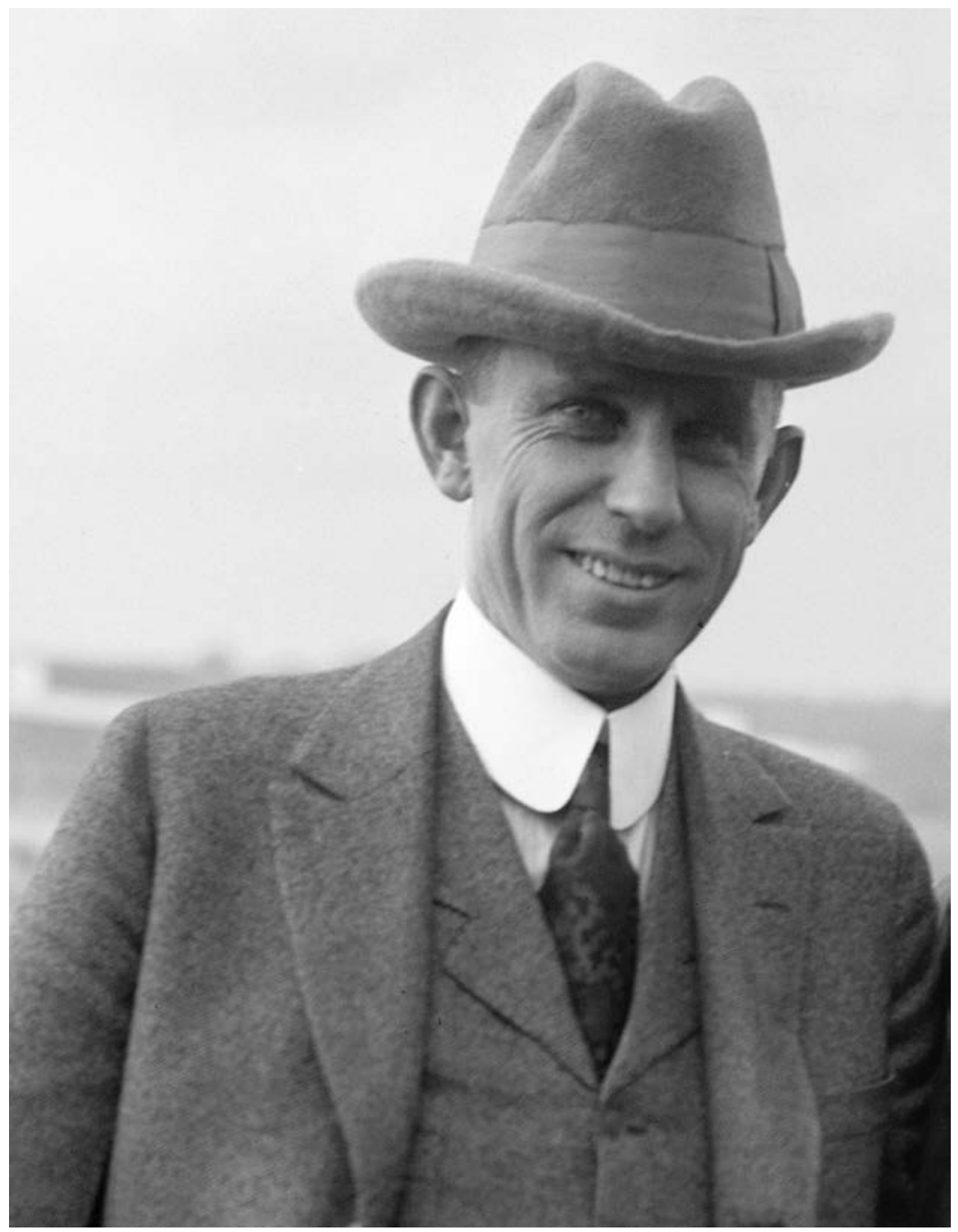

Figure 6. Rev. J. Frank Norris, c. 1920-25. The foremost southern fundamentalist of the pre-World War II era, Norris repeatedly warned his flock about the twin threats of evolution and communism. George Grantham Bain Collection, Library of Congress.

his office, Norris had shot and killed D.E. Chipps, a Fort Worth businessman. Norris claimed that Chipps had physically threatened him and that he shot in self-defense. In a 1927 trial in Austin, Texas, the jury agreed, and Norris was exonerated. ${ }^{35}$ But his reputation as the "shooting parson of Texas" was secure. ${ }^{36}$ As biographer Barry Hankins has suggested, "It 
seems that people were attracted to Norris not in spite of his brushes with the law but in part because of them." 37

They also liked his dramatic flair in the pulpit. After having great success preaching at a Kentucky revival in 1911, Norris adopted a more expressive, emotional style at First Baptist. One observer described the high point of a Norris sermon: "His movements were jerky and impetuous. His arms at high points wave like flails. He would yank out his handkerchief, fitfully mop his face with it and thrust it back in one pocket and then in another. Once for emphasis and to drive home [his point] ... he seized the Bible and pounded it with the palm of his hand." 38

His performance won over working-class Fort Worth Baptists and drove away wealthier parishioners, just as Riley had in Minneapolis. As Norris told one of his flock, "I would rather have my church filled with the poor, the halt, the lame, the sinning ... than to have it filled and run by a high-browed bunch." For the ever-growing congregation-which reached some three thousand by the early 1920s-Frank Norris was one of them. ${ }^{39}$

His flock also liked the fact that he did not back down in the face of his perceived enemies. Before the evolution wars of the 1920s, those foes included liquor dealers, corrupt politicians, profiteering employers, and the Catholic Church. Norris fought them with the weapon of the Searchlight newspaper, which he founded in 1917. From the beginning, Norris made it clear that it would not be a narrow church publication. Rather, it was "an independent weekly, which will deal with all matters social, political and religious." Initially considering the Searchlight an open forum, he soon was describing it as the "official organ" of the First Baptist Church. Starting in the early 1920s, the front-page masthead featured a drawing of Norris, standing at left, with a Bible in one hand and a searchlight in the other. Its light rays traversed the title of the newspaper and hit their target at the far right-a cape-wearing, tail-spouting, and pointy-hat-bedecked devil, who was cowering and seemed dismayed that Norris had exposed him. ${ }^{40}$ For many Texas Baptists in the 1920 s confronting satanic forces in the world, J. Frank Norris was their man.

During the 1920s, Norris was sure that the devil was in league with the communists and evolutionists. In 1923, he delivered an address to the Texas state legislature in support of a bill to ban the teaching of evolution 
in the public schools of the Lone Star State. After Representative J.P. Lane delivered the invocation to the assembled crowd of politicos, a fellow legislator introduced Norris as the pastor with the largest Sunday school in the entire country. Having lobbied at the state capitol against organized gambling and for prohibition, Norris was a familiar figure among Austin lawmakers, and he began his long speech with joking reminiscences of those early days. His easy rapport with the crowd is reflected in the fact that his speech was interrupted repeatedly with applause and laughter. ${ }^{41}$ Those audience interruptions point to the mobilizing function of such speeches. Norris did present ideas about evolutionary science, but his main aim was not to intellectually persuade. He aimed rather to move legislators into action. As did Riley, Norris accomplished this goal by focusing on the consequences of evolution for people's ordinary lives. ${ }^{42}$

After disposing with the preliminaries, Norris began his defense of the bill. To the accusation that the bill was anti-science, Norris held up the Bible as a source of true science. To the claim that the bill violated academic freedom, Norris relied on the majoritarian argument that Bryan would use to good effect in Dayton. Since the public believed in creation according to Genesis, and since they paid teachers' salaries, they were entitled to classroom content that did not undermine their children's precious faith. To the argument that the bill violated constitutional guarantees embodied in the First Amendment, Norris readily agreed that "no creed, no dogma, no tenet of faith" should be taught in the public schools. But all major Protestant denominations-representing the majority of Texans-agreed on the fundamental idea of creation, which meant that it was not a sectarian creed but rather good Christian common sense. To be sure, Norris allowed, if Buddhists or "Mohammedans" demanded mandatory teaching of their faiths, if Catholics insisted that papal infallibility were to be taught to all Texas children (or even if Baptists were to insist on requiring instruction in the theology of adult baptism), that would violate the Bill of Rights. But teaching run-of-the-mill Christian creationism in public school posed no constitutional issues.

In spelling out these points, Norris shifted back and forth between straightforward exposition and homey stories and amusing anecdotes to keep his audience's attention and to engage their emotions. In ridiculing the speculative and "unproven" nature of evolutionary science, Norris summarized humanity's evolutionary origins: "Away back yonder some 
time, nobody knows when, six million, six hundred million, six hundred billion (one fellow put it at a quadrillion, on the matter of time these fellows are very extravagant and a few billion years is immaterial with brains that deal in wild guesses)—away back yonder some time-when, nobody knows, something happened away back yonder somewherewhere, nobody knows, something happened away back yonder somehow, something happened, nobody knows how." After matters proceeded a bit further from protoplasm to tadpole to fish to nameless cave-dwelling animals, who grew hair and "began to devour each other for breakfast and dinner," human beings finally appeared. His account continued: "Those living in caves kept on growing and being in the shade had no need for the hair and that accounts for so many baldheaded men. (Laughter.) One day one of these hairless, tailless animals ran off and stole a suit of clothes and became professor of biology out here at the State University. (Applause. Applause. Applause.) ${ }^{m 3}$ Evolutionary science is full of partial evidence and unanswered questions. But the remainder of the speech made it clear that such evidence was irrelevant to the argument Norris was making.

The question that framed the last third of the speech, and the key to its central meaning and impact, was "What will evolution do for us?" What Norris really meant is, "What will evolution do to us?" The picture painted by Norris indicated that God-fearing Christians were the victims. Norris introduced this portion of his speech by answering the hypothetical question, "Why is it that you insist on the Genesis account of creation?" His revealing answer is that since the Bible is the foundation of society, and since evolution attacks that foundation, he must reject evolution. It is not a matter of inadequate evidence for an academic claim but rather a matter of moral, social, and, one might say, political obligation. "Destroy the foundation," Norris explains, "and the whole superstructure of society will give away [sic]." Under the sway of evolutionary ideas, Norris told legislators, "man is reduced to a mere machine." He no longer had any personal obligation to his Creator.

The consequences, as Norris then proceeded to illustrate, were dire. "My friends, we are in a terrible hour," he began. "Wave after wave of crime is sweeping over the land, and the reign of lawlessness is engaging the best thought of our engaging statesmen." Norris tipped his hat to Governor Patrick Neff, who had sent troops to quell an epidemic of "bootlegging, gambling, prostitution and robbery" in the oil boom town 
of Mexia, Texas. ${ }^{44}$ And yet, in the next breath, Norris shifted focus to "lawlessness" of a very different kind: "Last year I saw in New York a mob of 15,000 or 20,000 people. They had the red flag on the lapel of their coats. They waved them in their hands. A man would harangue a while and then a woman. They were ready to overthrow this government." His next example, concerning a group of defendants in Illinois who had been tried and acquitted of murder, also had strong political overtones: "Here a few days ago in Herrin, Illinois, a jury of twelve men lifted their hands to high Heaven and swore they would enforce the law. Red-handed murderers sat before them. There was no doubt about the murder. Nobody denied it. And yet these murderers were turned loose." The perpetrators of the 1922 "Herrin Massacre" were coal-mining union activists retaliating against company violence against their members. They received support from labor activists nationwide and were acquitted owing to the widespread sympathy with the United Mine Workers of America in the southern Illinois coalfields. ${ }^{45}$

After denouncing the Herrin verdict, Norris segued from the "crime wave" to the "wave of liberalism" sweeping the United States on the subject of gender relations and sexual morality. Using that redolent phrase made famous by newspapers attacking the Bolshevik regime, Norris proclaimed that "we are in the days of free-loveism." Whereas in days gone by, a divorce would ruin a woman's reputation, Norris explained, now a series of divorces was a ticket to "moving picture" stardom. Men who abandoned a wife and children no longer risked absolute disrepute. Women and girls were now even rivaling men in their criminal capacities. "I could tell you story after story tonight," said Norris, "of the shame and disgrace of 12 and 14-year old girls and high school girls who have gone to drinking and smoking cigarettes and who are throwing to the winds the priceless jewel of womanhood."

Finally, there was Russia. The threat was spiritual and military. Norris offered his own version of the effigy-burning in Red Square. It was not "Jesus" but "God" who was destroyed by the flames. The culprits were "students" led by their "professors." Even if this was one crowd in one city, America confronted a nation with 170 million atheists. But this was not all. German rationalism was the seed that had bloomed into full-blown evolutionary thought. Now that Russia and Germany were allied-through the Treaty of Brest-Litovsk-it was only a matter of 
time before the "hordes" reached France. America, foretold Norris, "is going in again." From world war to violent crime to sexual immorality to socialist revolution, the consequences of evolutionary thinking were monstrous.

If there was one prominent Christian fundamentalist during the 1920s who made it easy for readers and listeners to grasp the connections between evolution and communism, it was Gerald Winrod. Born in 1900 the son of a former saloonkeeper turned upstanding citizen and preacher, Gerald Winrod may have been particularly aware of the pressures weighing on Americans during the Jazz Age to not live "clean, Godly lives." It was not only his father's spiritual journey but his mother's experience of breast cancer and subsequent battle with morphine addiction that made an impact on him. According to family lore, prayer saved her life. The Winrods then shunned medicine and relied on God for their bodily and spiritual health. Gerald was even more devout than his parents, making him a "battering ram of righteousness," in the words of his father. The young Winrod started preaching at the age of eleven and began editing his own paper at twenty-one. He founded Defenders of the Faith in the wake of the Scopes trial, angered by the evolutionary implication that Jesus himself was descended from the animal kingdom. In 1927, his fledgling Defender magazine reached sixteen hundred subscribers; by 1934, that number had grown to sixty thousand. ${ }^{46}$

Even before launching the Defender, Winrod was spelling out the moral, social, and political consequences of evolutionary teachings. He began with Christ Within (1925), a self-published collection of "lectures" he had been delivering around the Midwest. Like Riley, Winrod delivered carefully prepared lecture-like sermons, in contrast to the hellfire style of J. Frank Norris. ${ }^{47}$ Issued in four editions by 1932-with substantial revisions along the way-the book presented Winrod's defense of Christian fundamentalism and his attack on modernism and, more specifically, evolution. $^{48}$

In the opening chapter, Winrod contrasted the sinful "Adamic" man and the regenerate "Christ" man. The former had a heart filled with sin. From it issued all manner of modern evils: world war; the "crime-wave"; mass viewing of motion pictures that featured sex and vice; rising divorce rates; "rivers" of bootleg liquor; public dance halls as recruitment 
grounds for white slavers; and women who wore revealing clothing and who "smoke, drink, swear, and carouse as a man." 49 Winrod emphasized the noxious character of immorality by using olfactory language: garbage "rotting," "putrescence," "stench," and "putrid." ${ }^{50}$ In later editions of the book, Winrod offered a vivid picture of Satan, the force battling "the work of Christ in human lives." He stood atop a vast hierarchy of evil, with "millions" of demons at his disposal. He ran the equivalent of "a world-wide secret service department." And he was real—a figure with "huge, bat-like wings." 51

Winrod attacked evolution in his next chapter, "Mark of the Beast." Noting that premillennial dispensationalists used this phrase from the book of Revelation to forecast events during the period of the Tribulation, Winrod told readers he was using it instead as a synonym for evolution. It was a "diabolical doctrine" teaching that humans were descended from lower forms of life, thus giving "man" the "mark of the beast in his heredity." Winrod sidestepped debates about the details of premillennial dispensationalism but harnessed the emotional power of Revelation to identify evolutionary thinking with the Antichrist and the end times. He then proceeded in a populist vein to attack evolutionary scientists for veiling their fraudulent ideas in fancy language. "History discloses," wrote Winrod, "that all truly worthwhile knowledge has been within the reach of the common people." Quoting George McCready Price for support, Winrod concluded that evolution was a "guess" with no basis in fact. ${ }^{52}$

While calling out evolutionists for lack of evidence, Winrod also sought to ground his own argument in the philosophy of science. For Winrod, God's spiritual power was a physical force. Now that physicists had identified elementary particles as essentially consisting of energy, rather than mass, and energy was invisible-which Winrod defined as the "spiritual realm"-it was clear that spirit, not matter, was the fundamental basis of "reality." "Murky materialism," in Winrod's words, had failed. Ideas, which were based on human beings' unique God-given ability to reason abstractly, were the moving force of the universe. In a subsequent article, Winrod referred to our thoughts as "superphysical energies" and as "mental electrons." ${ }^{53}$ Here was a bold declaration of philosophical idealism based on the "new physics"-just what Lenin had in mind when he warned fellow Bolsheviks about Mach's ideas more than a decade earlier. 
But just as Price did not rest content to attack evolution on the scientific front, Winrod followed his review of the literature with a blatant political point. Not only was opposing evolution a matter of defending religion, he told readers, but "it is a patriotic duty also." According to the "wicked jungle doctrine," explained Winrod, morality is viewed as a mere convention; religion is a human-created phenomenon based on "hallucinations"; marriage was instituted by men to control women; and property rights were created by those who had property to hold on to it. Social evolutionary ideas constituted a threat to capitalist civilization. They spawn "anarchy and extreme radicalism" and were allied with the "defenders of the Red Flag." Summing up, Winrod echoed Bouck White's explosive metaphor. Evolution, he wrote, "is intellectual T.N.T." 54

Within the next year, as Winrod began to publish the Defender, his association of the moral and political consequences of evolution with the Bolshevik Revolution became more explicit and extensive. "Evolution Wrecks Youth" paraded a series of horror stories drawn from "Satan's cess pool" illustrating how teaching evolution in public schools created a "psychology of lust." He told tales of high school students participating in alcoholsoaked orgies ("whoopee parties") and male college students fighting over women at fraternity fests. In this early article, Russia came into the picture only as a joke. Students at the University of Kansas saw what they believed to be the work of student left-wing radicals-the Red Flag flying from an ROTC flagpole - which turned out to be a pair of "flaming bloomers." 55

One year later when Winrod reported with alarm on the radical student newspaper at Kansas called the Dove, the Bolshevik Revolution assumed a more prominent place. According to Winrod, the paper had mocked Christian ethics and the Defenders. In response, one Major M. A. Palen of the American Legion had pointed to the Dove as evidence of communism on campus and demanded the university ban it. Winrod supported Palen's demand and offered the supporting evidence, apparently with a straight face, that "the magazine always appears printed on bright red paper." Winrod was surely serious when he informed readers that "the principle of Evolution applied in the national life of Russia, poisoning its heart-springs, is largely responsible for the present chaotic condition existing there." ${ }^{56}$ The title of Winrod's article, "'Russia' in Universities," was doubly significant. It conveyed how he factually connected "Red Russia" to evolution. But the quotation marks around Russia and suggested how 
the Bolshevik Revolution had come to symbolize, for Winrod, a range of evolution-caused evils.

The fuller story on Russia and evolution emerged in Winrod's October 1926 Defender article titled "Russia's Mistake." Winrod opened by posing the question of whether or not it was "safe" to regard fellow humans as animals. The consequences of following the "beast" theory were the familiar litany of sexual perversion, crime, and moral degradation. Giving the example of a young woman who was learning about Haeckel's theory of recapitulation at a "certain state college," Winrod argued that the claim was factually false and was morally damaging to students. If such material had to be taught, students should be separated by sex. Simply by learning about the similarities between the physiology and embryology of humans and other animals in "mixed" company was dangerous. To these "fruits" of evolution, Winrod added one other that would later become central to the antievolutionist case: abortion. "To take the life of the unborn, according to the beast doctrine," Winrod wrote, "would be simply to destroy a forming animal."

Moving to the international stage, Winrod pointed to evolution's responsibility for war, immorality, and anarchy. It was, he said, "the devil's wrecking crew to the twentieth century." The signal case was revolutionary Russia. The Bolshevik masters had abolished organized religion, destroyed the churches, and made it illegal to teach children religion. As the "jungle consciousness" spread through the masses, marriage was widely spurned in favor of "free love." Men and women were pursuing sex with a single-minded focus and forgetting about their children. The result was that "335,000 waifs" were running in the streets of Russia like "little animals," riding the rails, and sleeping in abandoned freight cars. They were "victims of Evolution." 57

As further evidence of the disastrous effects of evolutionary thinking, Winrod quoted Clarence Darrow as favoring liberalized divorce laws; a psychology textbook that discussed "animal tendencies" in humans; and a University of Chicago professor who favored eugenics. To wind up his tour of evolutionist horrors, Winrod once more brought Russia back into the picture, for he was aware of the widely reported Bolshevik-funded project to interbreed humans with apes in French West Africa. He accurately cited Charles Smith of the AAAA as his source for the information that the Pasteur Institute would house the experiments, with $\$ 10,000$ 
contributed by the Russian government. Having now established that evolutionists were funded by communists to breed apes with humans, Winrod declared that "the great middle classes of people want nothing to do with such a putrid system of thought." Ever the populist, Winrod charged that an elite of evolutionists in the US were prevailing over the sensible "masses of American people." 58

Over the next five years, Winrod popularized the dangers of evolution in booklets such as Red Horse, as well as 3 Modern Evils: Modernism, Atheism, Bolshevism (1932). ${ }^{59}$ To help readers grasp the Russian connection, Red Horse provided a political cartoon. It pictured Russiapersonified as a bearded, barefoot peasant-standing on one side of a wall representing "U.S. Refusal to Deal with the Soviet Government." In the distance, beyond the wall, stood an American schoolhouse emanating, like the rays of the sun, a panoply of evil "communist" notions. They included evolution, animalism, disregard for God and the Bible, atheism, and immorality. As if to emphasize its importance, the word "evolution" appeared twice, once with and once without exclamation points. "'Taint Right!" complained the figure representing Russia. "Their government refuses to recognize me, but their schools steal all my ideas!"60

Like Riley, Winrod also kept his eyes on China. In 1927, Dr. Henry G.C. Hallock, an American missionary based in Shanghai, wrote to an American friend and Winrod supporter in Burton, Kansas, about the dramatic events there. Conservative warlord forces holding the city had just been defeated by an armed uprising of workers led by the Chinese Communist Party and the left wing of the Kuomintang Nationalists, opposed to the right-wing faction led by Chiang Kai-shek. It was the greatest victory up to that point in the long Chinese civil war, which would last, in fits and starts, another twenty-two years. "Wild Joy in Moscow on Fall of Shanghai," read the headline in the New York Times on the morning Hallock wrote his letter. "Tens of Thousands March to the Comintern Offices, Singing and Cheering in Streets," added the subhead. ${ }^{61}$ But Hallock was not cheering for the Nationalists. Led by the Communists, they had deceived the gullible Chinese masses with cries of "Down with imperialists! Give the people freedom!”

Hallock expressed this idea with an animalistic analogy. The people, Hallock wrote, were "like a flock of sheep." They are pursued by "maddogs or wolves—by men in the pay of Bolshevists." And if these agitators, 
these "beasts of men," show too much concern for the hardships of the people, the Bolshevists just find others to do the dirty work of stirring up the workers to go on strike and terrorize those who refuse to do so. As they yell out their false slogans, the Chinese Bolshevists are roaming the country "like fierce, wild animals." 62 In Winrod's terms, they bore the evolutionary mark of the beast. In a subsequent letter to the Defender, Hallock was more explicit about the thinking of the "terrible Bolshevists." In his view, they were "just Modernists gone to seed." ${ }^{63}$ If Winrod's readers needed it, here was yet another testimony to the poisonous effects of the beast doctrine.

Gerald Winrod, Frank Norris, and William Bell Riley were the most prominent members of the cohort of antievolution activists who led the charge during the 1920s and made a clear connection between the dual threats of evolution and socialism/communism. A lesser known but influential member of this group was Mordecai F. Ham Jr. (1877-1961), best known for winning a young Billy Graham for Christ at a Charlotte, North Carolina, revival in 1934. ${ }^{64}$ Born in rural Kentucky, Ham was the son and grandson of Baptist ministers. He preached widely throughout the American South, especially in Texas, and reached an even wider congregation through his weekly radio sermon from his eventual base in Louisville, Kentucky. ${ }^{65}$

Despite living nearly all his life in the South, Ham spent a brief sojourn in Chicago, from 1896 to 1900, working in sales. Then came an offer to join an acting company-his good looks and deep voice were useful in both sales and the theater. According to one account, "his father intervened to save him from such satanic influences." Just as George McCready Price discovered, it was difficult to avoid the snares of Satan in the big city. Perhaps it was his struggle with those temptations that led Ham to become an uncompromising moralist. He returned home from Chicago, spent some time in prayer and contemplation, and soon hit the revival road. In the next two decades, Ham became known for his hellfire preaching and soul-winning ability. ${ }^{66}$ By the 1920s, Ham also became known for an intense anti-Catholicism, which he shared with Norris, and for a deep belief, which Riley and Winrod would also soon adopt, in a satanic international Jewish conspiracy. ${ }^{67}$

Having spent much of his energies preaching against the demon rum over the previous two decades, Ham joined the campaign against 
evolution. From 1921 through 1924 he crisscrossed the state of North Carolina in service of that cause. While activists failed to secure passage of an antievolution bill the next year, Ham did reach thousands of North Carolinians with his fiery message. He also won the support of Governor Cameron Morrison, a conservative Presbyterian who attended a number of Ham's revival sermons. In January 1924, in a move of questionable legality, Morrison blocked the adoption of two biology textbooks for North Carolina public schools on the grounds that they taught that humans were descended from a "monkey." The illustrations of one of these drew special attention from the governor, who commented that "I don't want my daughter or any body's daughter to have to study a book that prints pictures of a monkey and a man on the same page." 68

The revival sermons Ham subsequently delivered in Raleigh were noholds-barred attacks on modernism. In response to the contention that humanity could work together to improve the world-the preeminent message of the Social Gospel-Ham took the position that all such efforts were pointless. There was no hope, except regeneration through Christ. "Show me one word in the New Testament that exhorts Christians to make the world a better place to live in," he dared his audience, "and you may hang me to a telephone pole." ${ }^{99}$ In another revival session, Ham again offered to submit himself to hanging, this time if anyone could identify a single fact that supported the theory of evolution. He blamed German rationalism for modernism, evolution, and worldliness, and he offered an appropriately violent Old Testament solution to the problem. If only the prophet Elijah had arrived in Germany thirty-five years earlier, lamented Ham, and "cut the heads off two thousand college professors"who were presumably tribunes of modernism-that would have saved the lives of thirty-five million, the casualties of the Great War, caused by evolutionary thinking. He also used the story of Elijah challenging apostate Israelites who had gone back to worshipping Baal. Ham pointed to the false Jazz Age gods that modernists were now supposedly worshipping when things turned against them. "Call upon your picture shows," mocked Ham. "Call upon your boxing matches, call upon your Venus, your Charlie Chaplin, call upon your evolution, call upon your modernist who makes my Christ the illegitimate son of an impure woman." 70

Finally, Ham addressed Russia. His sermon featured the story of Jehoshaphat, who nearly lost his life in a battle after allying with Ahab, 
who was under the influence of false prophets. For fundamentalists, the modernists were just such deceivers, and Ham reminded his audience that the devil prefers a "Christian to pull off his devilment." The stakes were nothing less than the souls of Christian children "who will be damned by the thousands" if good Christian parents did not take responsibility. The cautionary tale was Russia, "swept by bolshevism," and even the United States, to which the "disruption" had spread. In a signature line often repeated at the end of his evolution sermon, Ham warned, "The day is not far distant when you will be in the grip of the Red Terror and your children will be taught free love by that damnable theory of evolution." ${ }^{\prime 1}$ Evolution appears as a satanic force that breeds sexual immorality, violence, and political oppression.

Not all North Carolina residents shared Governor Morrison's enthusiasm for Mordecai Ham. After the Raleigh News and Observer criticized Ham for calling modernists "damned infidels"-a violation of the Third Commandment not to take the Lord's name in vain-Ham's choir director lashed out at News and Observer editor Josephus Daniels for having misquoted what Ham had actually said: "damnable infidels." ${ }^{72}$ But this spat paled in comparison with the war of words that Ham sparked during his visit that November to the small coastal town of Elizabeth City. There he butted heads with W.O. Saunders, the modernist editor of the local Independent, who took an unusually dim view of Ham's religion and politics. ${ }^{73}$

Ham's Elizabeth City revival sermons included the usual fare on sin and salvation, modernism and fundamentalism that he had served up in Raleigh earlier that year. But this time he added an ingredient that increasingly became part of the fundamentalist and creationist arsenal in the 1920s and 1930s: the Jewish conspiracy, which he tied to both evolution and communism. In a series of sermons in Elizabeth City-publicly rebutted by Saunders-Ham targeted the Jewish Chicago-based philanthropist and owner of Sears, Roebuck and Company, Julius Rosenwald. In Chicago, Ham charged, Rosenwald used his money and influence to promote prostitution, gambling, and the morally degenerate music of jazz nightclubs. Rosenwald had served on the Chicago Vice Commission, which turned a light on the racially segregated "vice" districts of the city. Though they recommended that the city act against all such activity, Ham led his listeners to believe that Rosenwald was in favor of racially integrating the 
vice industry. Houses of prostitution serving Black men would employ white women, thus raising the explosive prospect of "social equality."

Regardless of the details Ham cited about Rosenwald's activities in Chicago, his main point was that Rosenwald was part of a vast conspiracy, documented in the Protocols of the Elders of Zion, to corrupt and destroy the Christian world. The original version of the Protocols was drafted by ultra-nationalist journalist Pavel Krushevan, from the Russian province of Bessarabia (now Moldova). His Jew-hating articles that spread rumors of the Jewish blood libel helped spark the murderous 1903 Kishinev, Bessarabia, pogrom. ${ }^{74}$ Morphing into a tool employed by czarist police agents in the years approaching the 1905 revolution, the Protocols defended czarism by discrediting the revolutionary movement as essentially Jewish. The document's authors observed that Jews played a disproportionate part in Russian revolutionary movements, and in various sectors of the economy. To explain these undeniable facts, they fabricated a story about a secret world council of wealthy Jews-the Elders of Zion-who were quietly and invisibly manipulating world events. The heart of their strategy was to create disorder, demoralization, and desperation- "chaos"-which would render the world's peoples willing to yield control to a dictator supplied by the Jewish elders. One reason that journalists and scholars long ago concluded that the Protocols were a forgery-that the Elders of Zion did not exist-is that much of book is copied word for word from a novel written in the mid-nineteenth century by French political satirist Maurice Joly. Published in 1864, The Dialogue in Hell between Machiavelli and Montesquieu is a fictional conversation between the two diabolical plotters, which Joly intended as a veiled political attack on the Emperor Napoleon III. The true origin of the Protocols explains its literally and figuratively Machiavellian language. ${ }^{75}$

In explaining to the attendees at his revival tent meetings the cosmic stakes in the Rosenwald affair, Ham leaned heavily on Henry Ford. The auto industry mogul was the most prominent promoter of the Protocols in the form of a four-volume group of pamphlets called The International Jew, selected from articles run in Ford's company-funded newspaper, the Dearborn Independent, in 1920-21. ${ }^{76}$ According to The International Jew-which quoted from the Protocols extensively—a "cabal" of wealthy Jewish bankers was behind the plan Ford's editors called the "Jewish World Program.” In Ford's eyes, not only was Julius Rosenwald a typical 
member of this evil group, but he had sinned further by financing an exposé of Ford's anti-Semitic writings. The author who unmasked Ford was John Spargo, a former Socialist leader and devotee of the Darwin-Spencer synthesis. Spargo skewered Ford and opened his book by reprinting a statement against anti-Semitism signed by a long list of notables "of Gentile birth and Christian faith," including former presidents Woodrow Wilson and William Howard Taft. ${ }^{77}$

Readers of The International Jew learn that the Jewish plotters have introduced ideas to weaken and eventually enslave the "Gentiles." In Protocol 2, quoted in Ford's “'Jewish' Estimate of Gentile Human Nature," the Jewish masters brag about the "successes we have arranged in Darwinism, Marxism, and Nietzscheism" and the "demoralizing effect of these doctrines upon the minds of the Gentiles." Moreover, they explain, we will use our "Press" to generate "blind confidence in those theories." ${ }^{78}$ In "Does Jewish Power Control the World Press?" the editors underlined the importance of these systems of thought, which they called "the three most revolutionary theories in the physical, economic, and moral realms."79

Ford and his associates followed the Protocols closely in identifying Jews as the source both of economic oppression from above and proletarian revolution from below. But the Bolsheviks took center stage. Not only did The International Jew present a table listing the percentage of the staff of Soviet government agencies who were Jewish, in order to demonstrate the numerical superiority of Jews in the Bolshevik Party. It identified exactly what was most alarming about the "Jewish" Bolshevik Revolution. It was not state control of industry, but rather Jewish control of education, whereby they introduced "sex knowledge" to the minds of Gentile children in order to corrupt and weaken them. In other words, "It is the downright dirty immorality, the brutish nastiness of it all; and the line which the brutish nastiness draws between Jew and Gentile." 80

While not drawing in Darwin here explicitly, the image of the "brute" plays a role similar to that of the "beast" in Riley's, Norris's, and Winrod's accounts. The Bolsheviks were reprehensible because they acted like animals. Sex, animalistic imagery, and children stand at the center of The International Jew's claims about Jewish influence on American popular music. Bolstering their claims with the fact that Jews were disproportionately prominent in the music industry, the editors described "Jewish Jazz" as "Monkey talk, jungle squeals, grunts and squeaks and 
gasps suggestive of cave love." 81 Their use of "monkey" created strong evolutionary overtones.

In his sermons denouncing Julius Rosenwald, Ham drew freely on the Protocols tradition that Ford had amplified for millions of Americans. According to Ham, Satan was behind a shadowy, secret organization with a "tremendous banking connection" that acted through the Soviet government. His ultimate goal was to overthrow Christian civilization and install the rule of the Antichrist. Dutiful tools of the Jewish conspiracy and ultimately of Satan, the Soviets were seeking to undermine America with a revolution that would equalize all wealth. To "demoralize" Americans and make that revolution possible, Moscow was promoting the liquor industry, prostitution, "corrupt literature," dancing, jazz, Charlie Chaplin movies, universal suffrage (regardless of race, sex, or "intelligence"), and the "false philosophy" of evolution. Posing as "friends of the negro," the communist plotters aimed to draw African Americans away from the church and toward their own immoral communist schemes. They would stop at nothing to attain their goals. Moscow had assassinated President Harding and was infiltrating workers and farmers to bring down the American economy. The "modernists" in American churches were collaborating with the conspiracy, as shown by the support given by the proevolutionary "Bad Bishop" Brown to the Communist Party. "Darwinism is not a science," declared Ham, "it is a propaganda." ${ }^{82}$ Since that propaganda formed a key part of the diabolical Jewish-communist conspiracy, it had to be stopped.

Consistent with the conspiratorial connections that Riley, Norris, Winrod, and Ham had made by 1924 between evolution and communism, it comes as no surprise that the following summer, Rev. Timothy Walton Callaway chose to share damning facts "not generally known to the public" about the socialist-tainted background of defendant John Scopes. ${ }^{83}$ Callaway's own background went back to Americus, Georgia, where his parents were Sunday school teachers at the First Baptist Church. After a brief career working for the railroad and as a local grocer, young Callaway felt the pull of the ministry, and soon was ordained as a Baptist preacher. Several years later in Macon, a growing regional market and manufacturing center, he founded the Baptist Tabernacle in a working-class section of the city to minister to the needs of newly arrived migrants from the Georgia 


\section{FATHER OF SCOPES RENOUNCED CHURCH}

\section{Was Staunch Socialist and Follower of Debs.}

Born in England and in Early Life Held to the Presbyterian Faith.

BY THE REV. T. W. CALLAWAY. (Pastor. Baptist Tabernacle, Chattanooga.) Chattanooga Times speoial.

DAYTON, July 9. - The arrival in Dayton of Thomas Scopes, the father of our young professor, naturally causes interest to center around the early environment of the defendant in the evolution trial.

It is not generally known to the public that the father of young Scopes, was born and reared to manhood in England-afterwards coming to America, where the professor was born whose name has now become famous. It is to be sincerely hoped that the glory thus suddenly thrust upon the young man will not soon be forgotten, nor will he be left alone in bis newfound glory, unsung and unhonored.

An acquaintance of the Scopes family for seventeen years in Padueah, Ky., is authority for the statement that the elder Scopes was a machinist as far back as 1904 in the Illinois Central shops in Paducah. In the earlier years be was a professed Christian and a member of the Presbyterian church. Later he repounced his religion, became a stanch socialist and a faithful follower of Eugene Debs. It is claimed that Thomas Scopes was a man of strong personality, a fluent speaker, and could talk long and loud against the poditical and religious systems of America. It is also stated that he had quite an influence among bis fellow workmen

Figure 7. "Father of Scopes Renounced Church," 1925. Rev. T. W. Callaway's July 10, 1925, article in the Chattanooga Times red-baits defendant John Scopes as the son of a dangerous Socialist on the opening day of Scopes's trial for teaching evolution in Dayton, Tennessee. 
countryside. Perhaps this experience sensitized Callaway to the potential pull of socialist politics. By 1920, he had moved to take up the pastorate at the Baptist Tabernacle in Chattanooga, the city where he spent much of the rest of his ministerial career. ${ }^{84}$

Tarring Dayton mine manager and ACLU member George Rappleyea with the red brush, Callaway posed as a source of objective information for "the uninformed well-meaning public." Quoting from R.M. Whitney's Reds in America and the report of the New York State Lusk Committee that investigated labor radicals, Callaway argued that the ACLU was linked with communism through "interlocking directorates" with the aim of "penetrating" a variety of organizations to prepare for a violent general strike to overthrow the government. The ACLU supported "all subversive movements" and protected criminals. ACLU chairman Harry F. Ward, a Methodist minister, cooperated with the Socialist Party, the Industrial Workers of the World, and other "anti-American" movements. ${ }^{85}$ Since Callaway viewed the Scopeses and Rappleyea as part of the Communist conspiracy, he might not have been surprised a few weeks later to see John Scopes's "special” in the Daily Worker. Certainly there were other fundamentalists who noticed the attention that left-wingers were giving to the trial. As Indiana-born and New York-based fundamentalist John Roach Straton commented, "A large group of outside agnostics, atheists, Unitarian preachers, skeptical scientists and political revolutionaries ... swarmed to Dayton." 86

Callaway's fundamentalist political activism went beyond the Scopes trial. In Romanism vs. Americanism (1923), he had already warned about the threat to the separation of church and state posed by the "religiopolitico organization" of the Catholic Church. ${ }^{87}$ In 1926, Callaway cosponsored a resolution aiming to place the Southern Baptist Convention on record as opposing any theory that "declares or implies that man has evolved to the present state from some lower form of life." ${ }^{88}$ In 1934, when the first graduating class walked across the stage at fundamentalist William Jennings Bryan University in Dayton, Tennessee, Callaway gave the commencement address. ${ }^{89}$ Thus did the red-baiting of John Scopes become tied to a pioneer institution of American creationism and fundamentalism.

For all the connections that antievolutionists made between evolution and politics, they continued to insist that "true" science offered the most 
effective refutation of Darwin's ideas. In September 1925, just months after the Scopes trial ended, John Roach Straton paid tribute to the latest attempts by scientists of Christian faith, including George McCready Price, to refute evolutionary arguments. He was especially impressed with The Case against Evolution (1925). It was unusual in two respects: its publisher, Macmillan, was a major trade press, and its author, George Barry O'Toole, was Catholic. Straton thought that O'Toole's "logical grasp of the subject" and use of "scientific nomenclature" enabled him to strike a "deadly blow" to evolutionists..$^{90}$ O'Toole did review the scientific shortcomings of evolution. But he ended the book by arguing that evolution was dangerous to people of faith because it stirred social and political revolt.

George Barry O'Toole (1886-1952) was born in an Irish working-class neighborhood of Toledo, Ohio. He attended a local Jesuit college and then spent from 1906 to 1912 in Rome, earning his PhD and STD (doctor of sacred theology) from the Urban University. After doing a stint as an army chaplain during World War I, O'Toole took a position teaching theology and philosophy at the Benedictine Saint Vincent Archabbey in Latrobe, Pennsylvania. Having taken a few science courses at Columbia University, O'Toole was hired to teach an animal biology course at nearby Seton Hill College, enabling him to describe himself as a "biology professor." ${ }^{91}$ In an age that lacked for creationist PhD holders, this designation, however specious, lent legitimacy to the cause. Citing O'Toole's work in the late 1920s, Gerald Winrod referred to him as a "scientist of recognized standing." 92

Initial responses to Darwin among Catholics had included some prominent voices favoring theistic evolution, most notably English biologist and Catholic convert St. George Jackson Mivart (1827-1900).${ }^{93}$ Mivart's On the Genesis of Species (1871), published the same year as Darwin's Descent of Man, defended the general idea of evolution-including the evolutionary origins of the human body-while arguing that Darwinian natural selection alone was incapable of explaining natural history. A God-infused process of "individuation" was necessary to explain embryological development, as well as the presence of the distinctly human soul. Mivart believed that a God-directed evolution was "perfectly consistent with strictest and most orthodox Christian theology." ing the relatively noncontroversial nature of Mivart's conclusions for the Catholic hierarchy, the "liberal" Pope Pius IX granted Mivart a pontifical doctorate in $1876 .{ }^{95}$ 
Many American Catholics agreed. Mivart's American counterpart was Notre Dame's John Zahm, a physics professor and priest in the Brotherhood of the Holy Cross. Zahm championed a theistic non-Darwinist evolutionism in his Evolution and Dogma (1896). He was initially tolerated by Rome and even secured a private audience with Pope Leo XIII. ${ }^{96}$ In the US, early responses to evolution suggested that Catholics did not feel threatened by Darwin. A number of prominent Catholic thinkers, including professor of theology John Gmeiner, claimed none other than Saint Augustine as an early exponent of evolutionary ideas. They found ways to reconcile their theistic evolutionism with a revival of Aristotelian neoScholasticism, promoted by Leo XIII starting in 1879, with its distinctive conceptions of the unity of form and matter. They also benefited from the absence of any papal pronouncements against evolutionary teachings. ${ }^{97}$

But the toleration of the likes of John Zahm did not last. Catholic proevolutionists soon became casualties of the Roman hierarchy's campaign against "modernism." The Roman Congregation of the Index banned Zahm's book in 1897. In 1899, Rome excommunicated Mivart for his increasingly heterodox views, particularly his rejection of the traditional view of hell. Perhaps the clearest statement from Rome of the antimodernist impulse was Pascendi Dominici Gregis (Feeding the Lord's Flock) issued by incoming conservative Pope Pius X in 1907. Pointing to the satanically inspired "enemies" of the church, Pius focused on those who are "hid" within the "very bosom and heart" of Catholicism, members of the laity and especially the priesthood who were spreading "poisonous doctrines." Because they attacked from within, these crafty characters were the most "pernicious" of all the church's enemies. Using a favored analogy from Jesus's Sermon on the Mount, the pope warned that such foes had struck at the root of Catholic truth and were spreading the "poison through the whole tree." Pascendi did not specify biological evolution as one of these poisons, but it did attack the concept that Catholic doctrine itself could "evolve." 98

The Catholic campaign against modernism also took aim at socialism. Chief among the ideological weapons employed by Catholic clergy were papal pronouncements beginning with Leo XIII's encyclical Rerum Novarum of May 1891, which was subtitled "On the Condition of Labor." The pope endorsed labor unions but also upheld the sanctity of private property. Furthermore, the pope instructed that "the main tenet 
of socialism, community of goods, must be utterly rejected, since it only injures those whom it would seem meant to benefit, is directly contrary to the natural rights of mankind, and would introduce confusion and disorder into the commonweal." His successor Pius X issued similar declarations in 1903 and then again in 1912. ${ }^{99}$ American Catholic lay activists took those declarations and ran with them. Among the most effective were Bostonians David Goldstein and Martha Moore Avery, both Catholic converts and former Socialist Party leaders, who hounded Socialist Party activists in the Bay State for decades. Their coauthored antisocialist diatribe, Socialism: The Nation of Fatherless Children (1903), flayed socialists for promoting "free love" and other forms of immorality. Boston's Cardinal William O'Connell, a militant antisocialist and strong ally of Rome's antimodernist campaign, gave the book his imprimatur. ${ }^{100}$

In The Case against Evolution, O'Toole spent nearly the entire length of his book reviewing the evidence and arguments for biological evolution. He began by describing the "crisis" in evolutionary science, citing William Bateson (a mutation theorist) on the "death" of Darwinism. He then devoted a chapter each to comparative anatomy and fossil evidence. For the former, he made good use of comments from T. H. Morgan about mutations in Drosophila melanogaster and how a series of intergraded species might seem to provide proof of historical development, but could instead be nothing of the kind. For the latter, he generously showcased George McCready Price's critique of the geological column and concluded that the argument for evolution from paleontology was "simply a theoretical construction which presupposes evolution instead of proving it." 101

O'Toole devoted the remainder of his biological discussion to the origins of life, the human soul, and the human body. Life, according to O'Toole, did not arise by spontaneous generation, but rather by divine action. But since the elements in organic creatures were already present in organic matter, explained O'Toole, this was not a supernatural act, nor was it a "miracle." Just as Winrod had described God as a physical force, O'Toole defined creation as a natural act of God. As for the human soul, O'Toole compared humans to animals with respect to sensation, instinct, and intelligence. He concluded that humans uniquely possessed the latter, defined as "the power of abstract thought," which "cannot be evolved from matter." Finally, O’Toole reviewed in some detail the considerable 
evidence from embryology, anthropology, and recently discovered fossils that suggested that humans and living apes shared a common ancestor. Not surprisingly, he concluded that the "connecting links between men and apes are found, on careful examination, to be illusory." 102

One might be forgiven, at this point in O'Toole's book-96 percent of the way through — for thinking that it was the evaluation of such evidence that guided the author's conclusions. But the key to O'Toole's thinkingand the dimension of his work that joined him to Riley, Norris, Ham, and Winrod-resided in his twelve-page afterword. Here he took up the cudgel against those who argued for evolution on the grounds of "materialistic" and "metaphysical" "monism." These were partisans of evolution who were convinced of its truth because of its simplicity or based on the principle of Occam's razor. O'Toole objected to this logic on the grounds that "simple explanations are not necessarily true explanations." He also indicted such thinkers for adopting an "attitude" based on something other than "the actual results of research." And yet, O'Toole proceeded to do just this when he argued against evolution from the "standpoint of moral and sociological consequences." From this angle, O'Toole contended, the "gravest count against evolution is the seeming support which this theory has given to the monistic conception of an animalistic man." If man is a mere "brute," if free will does not exist, O'Toole continued, then there is no basis for morality, and all hell breaks loose in a "wake of destruction." In ordinary social life, this translated into "undermined convictions, blasted lives, crimes, misery, despair, and suicide."

There was also a political aspect. If there is no reward in heaven, then wrongs must be righted here on earth. It is time for the "proletariat" to take back the world from the "coupon-holding capitalists." In a nice anticipation of Orwell's Animal Farm, O’Toole used a porcine analogy. If we are just animals fighting for enjoyment, then "the starving swine must hurl their bloated brethren from the trough that the latter have heretofore reserved for themselves." This struggle portended the "disintegration" of civilized life. Such was already happening in the Russian revolutionary "reign of terror," added O'Toole, with the application of "Marxian Socialism," which is called scientific because "it is based on materialistic evolution." Summing up this analysis, O'Toole ended the book with an extended quotation from noted Italian Jesuit scholar and anti-Darwinist Giuseppe Tuccimei, who bemoaned the baleful effects of evolutionary 
thinking, its link with socialism and anarchy, and its growing acceptance among the "ignorant and turbulent masses." 103

O'Toole was hardly the first antievolutionist to deploy both scientificsounding as well as "fruitistic" arguments. But the degree of disproportion in space allotted to each argument was striking in The Case against Evolution, so much so that one reasonably wonders whether anyone bothered to read O'Toole's afterword. Reviews in Catholic journals do not mention it. ${ }^{104}$ But in at least one very prominent review in the Brooklyn Eagle, which dealt with O'Toole's arguments about science, the editors created a text box, designed to draw readers' attention to O'Toole's political argument. Headlined "What Marxian Scientific Socialism Has Done," it quoted a passage from his afterword text regarding Marxism's relation to evolution, the Bolshevik and French Revolutions, "free love," and suicide. The review's strategy paralleled O'Toole's in terms of quantitative coverage, but in contrast with the cleric, the newspaper's editors made sure their readers got the political message. ${ }^{105}$

For all of their differences in style, region, age, and religious affiliation, Riley, Norris, Ham, O'Toole, and Winrod agreed to a remarkable degree. Evolution was not only scientifically false and in contradiction to the truth of Genesis. It was a mortal threat to the future of human civilized society. It undercut any basis for a reliable moral code and so encouraged human beings to act as if there were no consequences for their actions. This explained why women were now smoking, drinking, cutting their hair short, and divorcing their husbands; why crime seemed to be sweeping the country; and why the socialist and communist movements, with their rejection of private property, the traditional family, and established sexual mores, were gaining ground. With its open embrace of evolutionary science and sociology, its aggressive actions to liberate Soviet women, its rejection of the value of the church, and its promotion of social and political revolt, the Bolshevik Revolution seemed to epitomize the satanic mark of the beast. 